Jayeon Lindellee*

\title{
Distributive Consequences of Risk Privatization: The Case of the Swedish Unemployment Insurance System
}

\author{
https://doi.org/10.1515/zsr-2020-0010
}

\begin{abstract}
The public unemployment insurance program in Sweden has retrenched in terms of its benefit generosity in the last three decades. As a response to this trend, in which an ever-smaller proportion of the previous income of unemployed persons is compensated by public unemployment insurance benefit, complementary income insurance schemes provided by unions have expanded rapidly in the last 15 years, currently covering one half of the working population. What does this change mean for people who need income protection upon unemployment and are more likely to find themselves unemployed or underemployed? By analyzing survey-based benefit recipiency data among retail workers who were unemployed in 2014, this article explores the outcomes of the multi-pillarized unemployment benefit provision system in Sweden. While public unemployment insurance benefit does not fully compensate for the income loss for the majority of retail workers, the promise of a complementary income insurance scheme seems to be illusory for many individuals as they repeatedly oscillate between precarious work and benefits, accompanied by the burden of navigating a complex system.
\end{abstract}

Keywords: Ghent system, Privatization, Retrenchment, Sweden, Unemployment insurance

\section{Introduction}

This paper explores the outcomes of the risk privatization that has taken place in the Swedish unemployment benefit provision system. Beginning in the early 2000s, Swedish unions started providing complementary income insurance schemes to their members in response to the public unemployment insurance programme's lower benefit generosity, which began deteriorating in the 1990s. The complementary income insurance benefit allows the unemployed to top up their unemployment insurance benefit from the public programme, and as of

Ә Open Access. (C) 2020 The Author(s), published by De Gruyter. (c) BY This work is licensed under the Creative Commons Attribution 4.0 International License.

*Contact: Jayeon Lindellee, PhD, School of Social Work, Lund University, Box 23221 00, Lund, Sweden, email: jayeon.lindellee@soch.lu.se 
2017, the coverage of this complementary pillar reached one half of the working population in Sweden (Lindellee 2018). The emergence of the second pillar, in addition to the public pillar that provides de facto flat-rate benefits, is an empirical development that several scholars have anticipated. For instance, having reviewed the development of the Swedish welfare model after the economic crisis of the 1990s, Palme et al. (2002: 344-345) pointed out that, when the benefit ceilings in social insurance programs are not raised in tandem with wage increases, private insurance schemes are likely to develop.

The establishment of complementary benefits that top up the public pillar has previously been understood as a mechanism that leads to undermining the first pillar - which provides full compensation for income loss for low-income earners only - as it weakens a broader political foundation for encompassing welfare provision (Gordon 2019; Korpi/Palme 1998). Yet, the fact that the unions have actively taken up the role of collective intermediary in this case of risk privatization means that the extent to which income insurance schemes rely on the actuarial relationship between an individual's unemployment risk and insurance premium has been alleviated. In a comparative study between Sweden and Denmark, Rasmussen (2014) comments that Sweden is a case in which a relatively successful multi-pillarization of unemployment benefit provision has been achieved by restoring the principle of income replacement for a large part of the working population. This is in contrast to the Danish case, in which the development of complementary income insurance schemes has been limited.

However, it would be hasty to conclude that the establishment of the complementary income insurance schemes successfully compensates for the retrenchment of the public unemployment insurance program in its benefit generosity. Instead, we ought to tap into the actual take-up of the benefits among unemployed individuals in order to understand the outcomes of the change. Thus, I ask the research question guiding this paper: To which extent does the multi-pillar system of unemployment benefit provision cater to the needs of a labor market group facing a relatively widespread risk of unemployment and underemployment?

In this study, the choice of the retail sector - which employs around 9\% of the total number of employees in the private sector in Sweden - is informed by an understanding of a dualization tendency in the labor market structure. That tendency means there is an increasingly pronounced inequality between "insiders" (i.e. people with standard employment terms) and "outsiders" (i.e. people with atypical and precarious employment that deviates from standard employment relations entailing full-time, stable and fully insured employment) (Häusermann/Schwander 2012: 29-30). To understand the impact and out- 
comes of changes in the Swedish unemployment benefit provision system, I take a close look at a labor market sector characterized by a relatively high presence of outsiderness. This choice is motivated by the fact that, if we only study the impact of reforms by examining the situation of average workers, many retrenchment reforms that significantly affect labor market outsiders are not captured well (see, for example, arguments by Ferragina and Seeleib-Kaiser (2011: 598)). As there is a lack of benefit recipiency data on union-provided complementary income insurance schemes, a survey study was conducted, targeting the unemployed who received public unemployment insurance benefit in 2014 via the insurance fund that organizes retail sector workers. The analysis of the 1,134 respondents' answers forms the main empirical basis of the paper.

The paper proceeds as follows: Section 2 accounts for the important backgrounds of the study, the first of which concerns the emergence of complementary income insurance schemes in Sweden, and the second of which is about the labor market characteristics of retail sector workers and why it might be considered a site of precarious labor. Section 3 provides some theoretically anchored motivations for why it is important to study the distributional outcomes of risk privatization, as well as how the recent debate on social protection dualization works as an important insight into understanding the empirical case at hand. In Section 4 I motivate the choice of survey-based benefit recipiency study and describe the population and sample. Section 5 presents the main findings, highlighting the ways in which the public pillar of the unemployment benefit provision system is failing to provide adequate income protection for unemployed retail workers, as well as how the complementary pillar for this particular population appears to be illusory. The paper then concludes by pointing out that the current multi-pillarized unemployment benefit provision system in Sweden is rather poorly aligned with the increasingly dualized labor market. Workers in the periphery find themselves constantly in and out of work, while the benefit system still entails rigid institutional features that demand a long, uninterrupted employment record in order to qualify. 


\section{Background}

\subsection{The emergence of complementary income insurance schemes in Sweden}

Since the changes in the 1990s, the formal replacement rate of earnings-related unemployment insurance benefit in Sweden has remained stable. However, the lack of benefit indexation, in addition to several extended periods of indecision by respective governments in adjusting the benefit ceiling, has effectively and continuously reduced the generosity of the benefits. In fact, for the majority of wage earners today, the earnings-related unemployment insurance benefit level has decreased (Figure 1), meaning that there is a clear discrepancy between the goal of unemployment insurance benefit, which is to replace $80 \%$ of workers' lost income, and the reality.

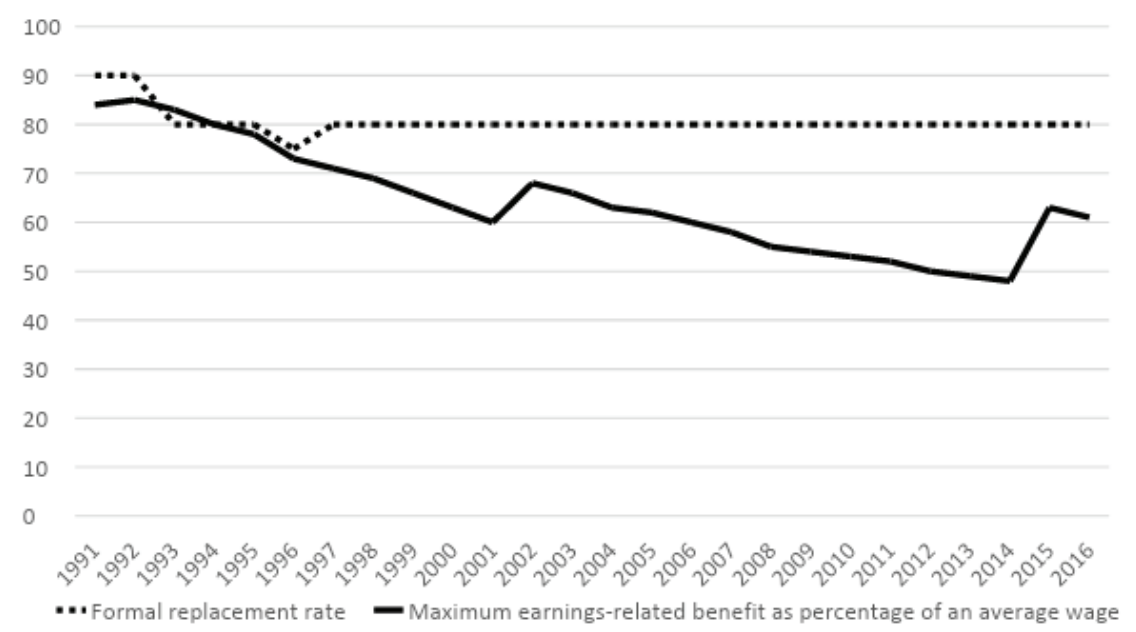

Figure 1: Changes in the formal replacement rate compared to maximum benefit levels in relation to the average wage each year, 1991-2016

Source: Benefit level from the Swedish Unemployment Insurance Board (IAF) and average wage for each year from Statistics Sweden (SCB). Note: Data on daily benefit payments from IAF were used to calculate the monthly benefit level, which was then divided by the average wage of each year in order to estimate the replacement rate as a percentage of the average wage.

The dotted line on the top of the graph illustrates the gross replacement rate, which has been stable at $80 \%$ since 1997 . The straight line illustrates the maxi- 
mum benefit amount as a proportion of the average wage for each year, showing a consistent decrease, with the exception of 2002 and 2015, when the benefit ceiling was raised. In 1994, unemployment insurance benefits could compensate for $80 \%$ of the previous earnings of an average wage worker. In contrast, two decades later, an unemployed person earning the average wage fulfilling the eligibility criteria for earnings-related benefits could receive at most $48 \%$ of their previous income from the public unemployment insurance program. Even with the recent increase in the benefit ceiling in 2015, the average wage among private sector blue-collar workers, for both males and females, was already above the benefit ceiling in 2017 (SCB 2017). This means that most wage earners are unable to secure the formal replacement rate of $80 \%$ of their previous income. In other words, the effective income replacement rate for the unemployed, whose previous income was higher than the benefit ceiling, has deteriorated almost continuously, with the exception of minor, temporary increases when the ceiling was raised in 2002 and 2015.

In response to the continued deterioration of benefit generosity, unions began to provide complementary income insurance schemes guaranteeing full compensation for lost income above the benefit ceiling in the public program. Led initially by the unions that organized professionals with university degrees in the early 2000s, the unions for white-collar workers and the blue-collar unions started providing group-based income insurance schemes for their members, either in cooperation with insurance companies or by launching their own mutual insurance companies. By 2017, 35 unions provided their members with complementary income insurance schemes, covering half of the Swedish population in the active labor force (for an extensive overview of the existing complementary income insurance schemes, see Lindellee 2018). To illustrate the different levels of compensation for the income loss upon unemployment, let us consider the fictitious case of Anna, who belongs to the Union of Local Government Officers, Vision (Figure 2). 


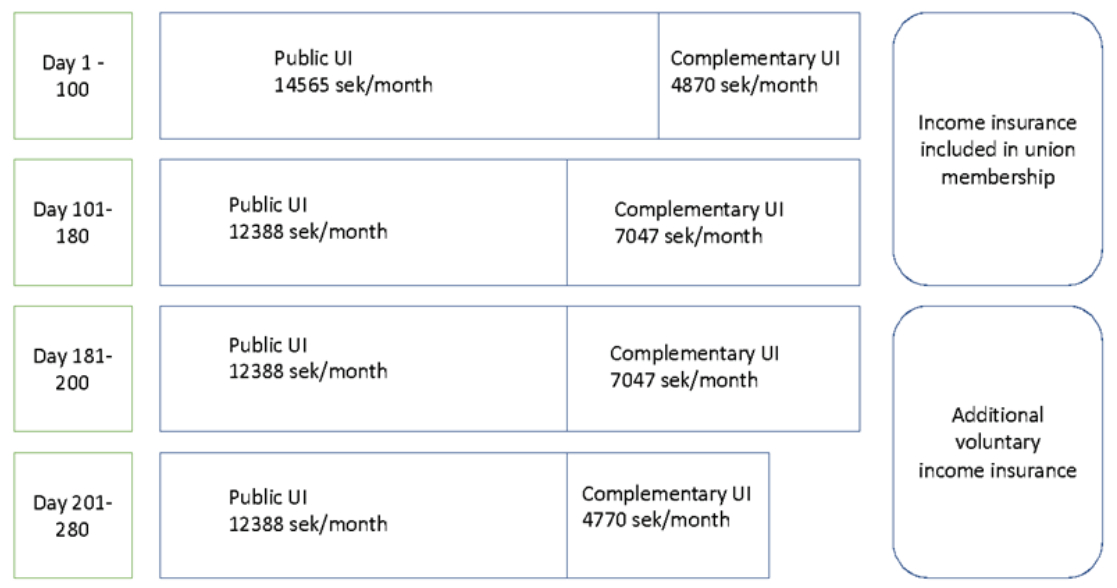

Figure 2: Illustration of benefit level with complementary income insurance benefits

Source: Lindellee (2018).

Anna earned SEK ${ }^{1} 34,000$ per month prior to becoming unemployed and has been a member of the union for more than a year. With the complementary income insurance included in her union membership, Anna may receive SEK 4,870 more per month during the first 100 days of her unemployment on top of the public unemployment insurance benefits (after tax) of around SEK 14,000. Between 100 and 180 days, the amount of the complementary income insurance benefits increases to SEK 7,047 per month, as the ceiling of public unemployment benefits already decreases from the 101th day of unemployment, while the income insurance still guarantees $80 \%$ of Anna's previous income up until the first 180 days of unemployment. In the event that Anna voluntarily signs up for supplementary insurance, which guarantees 100 additional days of complementary benefits for an extra monthly premium of SEK 75, the total amount of benefits up to the first 200 days of unemployment will remain the same at around SEK 19,000 per month. Then, starting on day 201, it will decrease somewhat, when the maximum income compensation level regulated in the law on unemployment insurance is reduced to $70 \%{ }^{2}$.

1 SEK 100 is equivalent to EUR 9.30.

2 SFS 1997:238. Lag (1997:238) om arbetslöshetsförsäkring. 
The establishment of this private pillar of the unemployment benefit provision system implies that the level of income protection upon unemployment varies. That variation depends on the individual employee's choice to join a specific union which, in turn, is restricted by the sector in which the employee works and/or the employee's occupation. Although the state's role in the Swedish public unemployment insurance program is restricted to regulation of the administration of independent unemployment insurance funds (the so-called "Ghent system"), it entails a redistributive ambition and a high level of collectivization of unemployment risks that vary among the working population. In contrast, the distributive logic governing the complementary income insurance schemes includes the actuarial principle between the unemployment risk and the insurance premium at an aggregated level that is limited to each and every union. Many, though not all, unions provide supplementary insurance schemes for an extra premium, guaranteeing a longer benefit period or a higher benefit ceiling. In this respect, the assessment of the premium takes place at the individual level, taking into account demographic and employment-related factors - representing the highest level of individualization of risk protection (Lindellee 2018).

\subsection{The retail sector as a site of precarious labor}

In order to understand the outcome of a risk protection system such as unemployment benefit provision, it is important to consider the interplay between the institutional features and the specific labor market characteristics of a given working population. Here, I contextualize the empirical study of unemployment benefit recipiency among retail workers by describing how the Swedish labor market is characterized by a dual structure between insiders and outsiders, the latter being disproportionally overrepresented among younger, female service sector workers in particular. The retail sector, and specifically its front-line sales workers, represents this more vulnerable and weaker group in the Swedish labor market today.

Compared to other OECD countries, Sweden has come to establish a highly dualized job security framework, as governments have deregulated temporary employment contracts while restrictions on permanent contracts have remained largely intact (Davidsson/Emmenegger 2013; Rönnmar/Numhauser-Henning 2012; Sebardt 2005). Most of the changes in the Swedish Employment Protection 
Act $^{3}$ have actually been about simplifying the possibility of using temporary employment (Berglund et al. 2017: 28). Davidsson and Emmenegger (2013), for instance, operationalize this phenomenon by quantifying the reform trends comprising the liberalization of the regulations relating to fixed-term contracts and temporary work agencies, combined with retaining the regulation of openended contracts. Among the 14 European countries included in their study, Sweden scores the highest in this measure of two-tier labor market reforms. Similarly, the changes in the OECD index score on the strictness of employment protection show that the protection of permanent employees in Sweden has not changed that much since the 1970s, while the index score measuring the protection of temporary employees has dropped significantly and is now below the average among the OECD countries (Berglund et al. 2017: 29).

The retail sector is a subsection of the private service sector and generally refers to service work "focused on and organized around the sale of products in stores", even though there is a myriad of subdivisions within the sector and different ways of setting boundaries as to precisely where the retail sector begins and ends (Coulter 2014: 20-21). In the official Swedish Occupational Register of Statistics Sweden (SCB 2016), the retail sector is represented by several categories of occupations, such as salespeople at stores (divided into stores selling specialized goods and supermarkets), sales managers at stores and warehouse, and distribution terminal workers. Front-line salespeople at stores are one of the occupational categories that employ many workers among people, but particularly among women. In 2016, for instance, salespeople at stores (including both types mentioned above) employed the second largest group of female workers in the Swedish labor market (115,690 individuals), second only to care service workers in the elderly care sector $(127,600$ individuals) (SCB 2016).

Workers in the retail sector have a vulnerable position, and this is reflected in the low average wage amounting to around $69 \%$ of the wages of industrial workers. Female workers in the retail sector in particular have the lowest wage level, while this very sector represents the largest number of female blue-collar workers (Vedin 2016). Another characteristic of the retail sector, likewise indicative of the relatively vulnerable and weaker position of its workers, is the high concentration of non-standard forms of employment. Both fixed-term employment and part-time employment are prevalent; for instance, around $28 \%$ of workers in the retail sector were employed through temporary contracts in 2015

3 SFS 1982:80. Lag (1982:80) om anställningsskydd. 
(Larsson 2015). The general trend in recent years has been for less secure forms of temporary employment, such as on-call employment (so-called SMSemployment), to become more commonplace when compared to relatively more secure forms, such as substitute employment or provisional employment. Some of the most widespread temporary forms of employment in the retail sector may entail the risk of inadequate protection in the social insurance system, since many entitlement rules are based on the norm of permanent and full-time employment. For instance, due to the widespread practice of overtime work, not only does involuntary part-time work have a fraction of working hours scheduled in advance (so-called zero contracts, as there is no guaranteed number of working hours), some retail workers have difficulties qualifying for unemployment insurance benefits (Berggren/Carlén 2016; Boman/Berge 2013; Boman/Strömbäck 2014).

Furthermore, there is a tendency for the low-wage retail sector to be seen as an inevitable entry point for young people starting their working life, as well as for people positioned furthest away from the labor market. In line with this view, the Swedish retail sector has the highest number of individuals with various forms of subsidized employment or who are on work training programs as a part of active labor market programs for the unemployed (Carlén/Berg 2015: 9). Together with the restaurant, cleaning and taxi industries, the retail sector has many instances of subsidized employment, even in relative terms (i.e. the number of employees with employer subsidies as a proportion of everyone employed in the industry) (Arbetsförmedlingen 2016). In recent years, the retail sector has also been one of the main target sectors in which the government has subsidized lower employer fees as a means of decreasing the unemployment rate, particularly among young people (Carlén/Boman 2013). Employer fees for hiring people below the age of 25 were almost halved during the period 2006-2016, although this policy turned out to have questionable effects on the unemployment rate among young workers (Egebark/Kaunitz 2013).

Thus, workers in the retail sector are characterized by their relatively weak position in the labor market, facing an impending risk of unemployment due to widespread temporary employment and involuntary part-time employment, as well as low salaries. This raises an important question regarding the extent to which the public unemployment insurance program - or complementary benefits for the unemployed, for that matter - cater to the needs of labor market groups that face the relatively widespread risk of unemployment and underemployment. 


\section{Theory: At the intersection of risk privatization and social protection dualization}

The development of complementary pillars of social protection involving private actors, or other types of collective intermediaries such as labor unions, represents a case of risk privatization in the following sense: First, compared to the state-run insurance programs with compulsory coverage, the complementary protection provided by group-based or individual insurance entails more limited risk pooling and thereby weaker redistributive mechanisms. When it comes to private insurance plans, their commercial nature strengthens the actuarial principle between the level of risk and premium, which raises the issue of accessibility for individuals with high-risk profiles. Hacker (2004) states the following regarding the distributive implications of risk privatization:

The bounds of social insurance thus delimit the scope of shared risk - the degree to which potent threats to income are spread across citizens of varied circumstances (risk socialization) or left to individuals or families to cope with on their own (risk privatization). To "privatize" risk, in this parlance, is thus to fragment and undermine collective insurance pools that offer reduced cost protection to higher-risk and lower-income citizens in favor of arrangements that leave individuals and families responsible for coping with social risks largely on their own (Hacker 2004: 249).

Hence, when a multi-pillar strategy is adopted in a risk protection system, it is important to ask the following: Can the combination of protection, provided by different pillars involving collectively negotiated group insurance plans and private insurance plans, provide adequate coverage for all types of risks that span different demographic groups and occupational sectors (see, for example, Ebbinghaus 2001; Meyer et al. 2007; Wiß 2015)? In the presence of multiple sources of welfare provision, it matters to which extent and in which ways individuals may combine different kinds of benefits, as does how these benefits help them cope with their financial vulnerability.

Thus, the multi-pillarization of risk protection systems entails greater responsibilities for individuals: They ensure an adequate level of protection against risks by making a range of active choices in relation to private complementary insurance schemes, as well as - in the case of group insurance provided by unions - by choosing the right sector or occupation in which to work. In other words, the outcomes of a multi-pillar system of social protection hinge greatly on the strategies adopted by individuals, as well as their knowledge and ability to navigate the system. 
Previous studies of the Swedish unemployment benefit provision system have pointed to two difficulties: gaining a comprehensive understanding of the range of income protection schemes comprising multiple types of benefits, and highlighting the fact that not everyone who is supposed to qualify for complementary benefits actually receives such benefits (Lindquist/Wadensjö 2007; 2011). Thus, the consequences of changes in a risk protection system, such as the changes in unemployment benefit provision, ought to be studied differently. That is, not only by examining changes in formal rules or the aggregate numbers of membership coverage, but also by examining actual benefit recipiency, as well as how unemployed people perceive the increasingly more complex and fragmented benefit system when attempting to cope with their income loss.

In this respect, some recent scholarly discussions on social protection dualization provide an important framework for examining the consequences of risk privatization.

Scholars have argued that labor market segmentation and inequalities in the working lives of insiders and outsiders in post-industrial economies are reinforced in the realm of welfare provision, which tends to consolidate the inequalities found in the labor market by institutionally reinforcing this duality, even in the institutional architecture of welfare provision. In other words, the dualistic structure of labor market segmentation is reflected in the institutional structure of welfare provision (Davidsson/Naczyk 2009; Kvist/Greve 2011; Palier/Thelen 2010; Seeleib-Kaiser et al. 2011).

Seeleib-Kaiser, Saunders and Naczyk (Seeleib-Kaiser et al. 2011) define social protection dualization as "a widening, deepening or the creation of new social protection dualism between insiders and outsiders." Insiders are here defined as individuals who either have access to comprehensive public and/or statutory social protection, or those whose public and/or statutory entitlements are complemented or supplemented by private and/or occupational social protection to a level that maintains their living standards. In contrast, outsiders are defined as those who would have to rely on (largely means-tested) public provision, primarily intended to reduce poverty rather than maintain living standards (Seeleib-Kaiser et al. 2011: 85).

The unemployed retail workers in this study most likely share many characteristics with the labor market outsiders, as described in the previous section of this paper. The present study does not attempt to explain why social protection dualization takes place. Instead, it is concerned with the actual distributional outcome of the institutional changes described in the previous section, as well as how it could be understood through the lens of social protection dualization. As will become clearer in Section 5 of this paper, the empirical study of the ac- 
tual benefit recipiency among labor market outsiders points to the relevance of the discussion about social protection dualization in understanding the consequences of risk privatization in the unemployment benefit provision system in Sweden.

\section{Method: Survey-based benefit recipiency study}

Thus far, survey-based benefit recipiency data have rarely been used in welfare state research, as compared to social expenditure and entitlement-related data, despite their analytical potential in assessing the quality of social protection systems (van Oorschot 2013). Despite the general problem related to the accuracy of self-reported benefit recipiency (Hernanz et al. 2004: 16), there are several aspects that motivate the choice of conducting a survey for this particular study.

First, in a rapidly changing terrain of public and private mixes of welfare provision, no recipiency data are readily available for different kinds of benefits. While benefit recipiency for public unemployment benefit is available in the statistical database run by the Swedish Unemployment Insurance Board (IAF), no institutional actor collects equivalent data for complementary income insurance benefits. Thus, in this case, collecting first-hand survey-based benefit recipiency data turned out to be a viable way of exploring the unknown emerging phenomenon in the Swedish unemployment benefit provision system.

Second, when it comes to privately provided unemployment insurance benefits, the coverage on paper does not serve as a good proxy indicator for the actual take-up of benefits among the unemployed. This is because workers who face a lower and less frequent risk of unemployment (so-called labor market insiders) tend to have significantly greater coverage of such benefits. Thus, the access of unemployed individuals to such private complementary benefits is considerably more limited than what might be suggested by an analysis of coverage and eligibility rules. Hence, it was fruitful to gather data on the relative number of benefit recipients (the number of benefit recipients in relation to those who are in need), as well as the actual amount of benefits from complementary unemployment insurance received by unemployed individuals.

Third, survey data may highlight gaps in benefit coverage (van Oorschot 2013: 231), revealing the extent to which the existing benefit provision system fails to cater to the needs of some unemployed individuals. By asking about the extent to which unemployed individuals turn to personal solutions - such as temporary loans and inter-family transfers - to cope with their income loss, the extent of the use of non-institutionalized, personal solutions by the unemployed individuals could be addressed. 
I use the term benefit recipiency study in an attempt to encompass the following aspects of the outcome of an unemployment benefit provision system: The first aspect is simply how many unemployed individuals actually receive the different types of unemployment benefits that are available. This gives us the actual coverage of the different benefits among those in need of income protection. Second, the outcome may also be measured by asking the recipients themselves to assess the extent to which their loss of income was compensated, as well as by tapping into the unemployed individual's perception of the adequacy of the benefit. Lastly, using the survey respondents' answers to openended questions, I tap into the subjective dimension of the outcome, which is related to the experiences of unemployed retail workers in their encounter with the unemployment benefit system.

The survey population comprises retail workers receiving public unemployment insurance benefits via the Swedish Commercial Employees' Union's (hereafter referred to as Handels, which is the Swedish name) unemployment insurance fund in 2014. Handels is the third largest union within the Swedish Trade Union Confederation (LO), representing 154,000 members working in the retail sector. It provides complementary unemployment insurance benefits for its members with an income above the maximum benefit level of the public unemployment insurance program. The sampling process took place in collaboration with Handels' insurance fund, as well as the union.

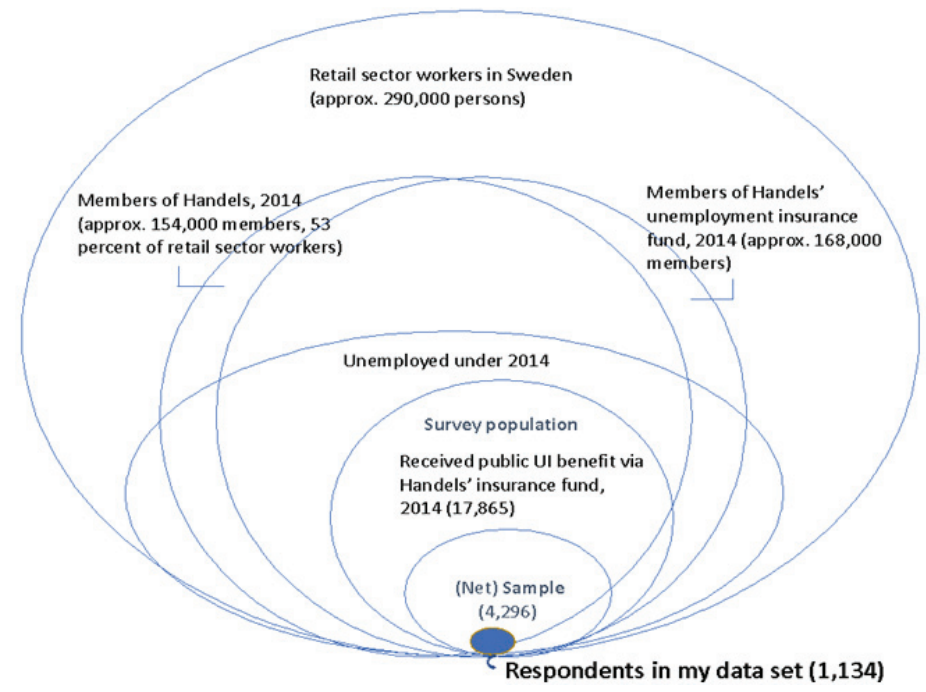

Figure 3: Survey population and sample in the larger context

Source: Author. 
According to statistics from the Swedish Unemployment Insurance Board, 17,865 individuals received benefits from the public unemployment insurance program via the insurance fund of Handels in 2014, which comprises the survey population. Through random sampling, 4,296 individuals were included in the final sample. Figure 3 illustrates the survey population and sample in context. It is estimated that around 53\% of all retail workers were organized by a union in 2014 (Kjellberg 2017b: 14) and the most prominent union for retail workers, Handels, had around 154,000 members in 2014. It is commonplace for Handels members to also belong to its unemployment insurance fund, which had approximately 168,000 members in the same year. As illustrated in the figure, it is important to keep in mind that not all unemployed individuals who worked in the retail sector are included in the survey population. This is because the sampling process was conducted by approaching unemployed individuals who received public unemployment benefits through their membership in Handels' insurance fund as described above. This means that the survey population excludes those individuals who were neither members of Handels nor members of Handels' insurance fund, as well as those individuals who were members of Handels but perhaps belonged to another insurance fund than Handels. The survey population also excludes individuals who were members of Handels and Handels' insurance fund but who did not receive any benefits.

From the sample of 4,296 individuals, a total of 1,134 survey responses were collected (response rate 26\%). The survey comprises 43 questions related to various types of unemployment benefit recipiency. Besides direct questions about the amount of benefits received, other questions addressed the following: i) knowledge of different unemployment benefits; ii) experience of accessing benefits; iii) strategies employed in coping with income loss and job seeking; iv) perceived financial security and the importance of complementary benefits during the period of unemployment; v) experience of employing other personal financial solutions in coping with an extended period of unemployment, etc. The survey was sent out digitally to the email addresses of the individuals in the sample, obtained through a collaboration with the insurance fund for the retail workers.

As there is no available register-based recipiency data for complementary unemployment benefits, the survey-based benefit recipiency study contributes with its attempt to provide a more comprehensive and realistic understanding of the outcome of the unemployment benefit provision system. Yet, the fact that the survey population only includes the recipients of public unemployment insurance benefits, but excludes unemployed individuals who have no access to the public scheme, is a clear limitation in understanding the outcome of unem- 
ployment protection for the most vulnerable group. Another limitation in the survey data used in this study is that the study does not take into account the probable impact of household characteristics in the individual's financial circumstances during their period of unemployment. In the following section, I present some key results of the analysis of survey responses regarding two aspects: firstly, the role of public unemployment insurance benefits and, secondly, the role of complementary income insurance benefit.

\section{Results}

\subsection{The crumbling public pillar: A rigid institution in a flexible labor market}

The public unemployment insurance program in Sweden comprises two parts: earnings-related benefits, conditional upon contributing to an insurance fund for more than 12 months, and the work requirements ${ }^{4}$ and basic benefits, which may be paid out if an individual meets the work requirements but not the membership requirements. In this section, I discuss the extent to which the goal of income replacement is achieved by public unemployment insurance benefits. I do this by presenting the benefit amounts received by the survey respondents and the kinds of financial consequences they faced.

\subsubsection{Income replacement (not) at work}

Among 1,134 survey respondents, 50\% (564 individuals) reported that they received SEK 680 in daily benefits, which was the maximum amount of earningsrelated benefits from the public unemployment insurance program in 2014. $10.9 \%$ received basic level benefits (SEK 320) or less, and 26.2\% received something in between the basic and maximum level. Taking into account the labor market characteristics of the unemployed retail workers described in section 2 , the fact that one half of all survey respondents received the maximum level of public unemployment insurance benefits speaks to the extent to which the pub-

480 hours per month for at least 6 months during the 12 months immediately preceding unemployment, alternatively, 480 hours during 6 consecutive calendar months and at least 50 hours in every single one of those months.

5 SEK 100 is equivalent to EUR 9.30. 
lic pillar of the unemployment benefit system has weakened in terms of benefit generosity.

Among those receiving the maximum level of benefits, $86 \%$ (485 individuals) had a previous income above the benefit cap of SEK 18,700 (as of 2014). In other words, despite the relatively lower average income level of unemployed retail workers, for approximately $42 \%$ of the respondents, the earnings-related benefits from the public unemployment insurance program were actually flatrate benefits that did not guarantee them $80 \%$ of their previous income. The maximum level of public unemployment insurance benefits, which one half of the respondents received, would have amounted to just above SEK 10,000 per month in 2014. This was actually lower than the average level of the meanstested social assistance benefits provided by local governments in Sweden, although the exact amount of social assistance benefits may vary considerably in practice depending on the recipients' situation (SSR 2014).

One way of capturing the actual outcome of the unemployment benefit system is to directly ask the unemployed person how much disposable income they had during their period of unemployment. For this purpose, the respondents were asked to write down how much money they had per month, including every kind of cash benefit and contingent income when they were unemployed. The respondents had an average disposable income of around 55\% of their previous income. But an obvious question remains: How did they manage their living expenses if they only received one half of their previous earnings?

Not surprisingly, being unemployed left the respondents with various financial problems. For instance, 35.4\% of the respondents could not pay their bills on time. $77.7 \%$ of the respondents stated that they had to cut down on expenses, such as visiting the doctor, private pension savings, exercise and visiting the family. Among respondents who shared their living expenses with a partner (54.5\% of all respondents, 618 individuals), 32.1\% stated that their partner had to work extra in order to compensate for the loss of household income. Overall, most respondents (84.1\%) felt that it was difficult to make ends meet when they were unemployed. Nearly one half of the respondents (46.4\%) experienced long-term consequences, such as debts.

Another indicator used for measuring the adequacy of income protection for the unemployed is whether or not an individual has the financial margins to cover unexpected expenses. According to EU-SILC data, four out of ten European citizens in 2014 lacked financial margins to cover unexpected expenses. For the Swedish population, the amount of cash applied to this question is SEK 10,000 . While the corresponding figure for the entire Swedish population was $18 \%$ (SCB 2014), among the survey respondents comprising retail sector workers 
who were unemployed in 2014 , as many as $65.9 \%$ lacked cash margins to face unexpected expenses.

The survey responses above should be seen as a snapshot of the financial situation in which the respondents found themselves. As there is no prior reference point of measurement for the respondents' answers to these questions, it is difficult to assert that these financial circumstances are a direct consequence of unemployment.

\subsubsection{Unemployed, yet constantly working}

There is another very salient characteristic among the benefit recipients that deserves attention: a high proportion of unemployed retail workers oscillates between work from which they cannot generate a sufficient income to make ends meet and part-time unemployment benefits, creating a constant administrative burden. Almost one half of all survey respondents (44.9\%, 509 individuals) were part-time unemployed, meaning that they retained part-time jobs while receiving unemployment insurance benefits for the period they were not working. The following comments exemplify how these unemployed retail workers combine part-time unemployment benefits with extra jobs, often in the form of on-call employment.

A-kassan [benefits from the public unemployment insurance program] plus the ten different jobs I had during those two years while I was unemployed were my only income. None of those jobs had enough hours. Sometimes I had six jobs at the same time. I said yes to all extra hours I could get and I'm actually lucky to have a colleague whose kids are often ill so that I can cover her shifts.

I was unemployed for 5 years and during that time I worked as an on-call substitute at a store on an hourly wage. I haven't had a permanent position up until now so I struggle a lot everyday as a single mother with three kids, just to make ends meet. Sometimes I work 10 days in a row, or a day and a night shift on the same day because I never know if I will get called in again if I would say no to them. They always need extra staff but just want to save money. So instead of hiring people like me who are unemployed, we are called in all the time and have to live with the stress.

For many retail workers, the boundary between employment and unemployment does not seem to be all that clear-cut. Many of them are part-time unemployed, combining varying amounts of work from one week to the next with unemployment insurance benefits, constantly looking for extra hours or fulltime employment, which is increasingly harder to get, all the while having to 
deal with the bureaucracy of receiving the benefits, which involves the difficult task of collecting documentation from employers on the hours worked.

It's a shame that you are forced to become unemployed instead of working as much as you can. I sometimes had to take time off so that I could visit the Public Employment Service office. It was difficult to complete and submit all the papers from the different employers for which I worked. The fact that you have to deal with more paperwork because you managed to get a part-time job is so ridiculous. Having to ask for papers from a temporary employer whom I maybe haven't even met or talked to is not easy.

Hence, the unemployed are not workless at all but are occupied with temporary jobs as well as bureaucracy. This "work-for-labor" work that does not directly lead to a wage but is nevertheless an integral task for someone on the periphery of the labor market with no stable employment (Standing 2014: 206-207) is a recurring theme in the stories of the unemployed retail workers recounted in the commentary fields in the survey.

The pattern of oscillating between precarious employment and unemployment and the widespread use of informal solutions in dealing with income loss indicate how the existing institutionalized benefit system does not provide adequate protection for unemployed retail workers today. What Standing (2014: 81) refers to as the "precariarity trap" seems to capture the situation in which many unemployed retail workers find themselves. Namely, people with unstable patterns of labor market participation end up in a negative spiral comprising of temporary and low-paid jobs, unemployment with low benefits, and being faced with demanding obligations as a job-seeker, which include temporary loans and family assistance when waiting for benefits, etc.

\subsubsection{Use of informal solutions}

According to a survey conducted by the Swedish Federation of Unemployment Insurance Funds (SO) in 2014, ${ }^{6}$ around one third of respondents stated that they had to borrow money during their period of unemployment. This indicates that a relatively high proportion of unemployed individuals in Sweden today are forced to seek other personal solutions in order to deal with income loss. The use of personal solutions in coping with income loss upon unemployment is a highly salient aspect, even when we examine survey respondents who had ac-

$674 \%$ of 5,143 members contributing to 27 different unemployment insurance funds who were unemployed in February 2014 responded to the survey. Press release by SO, June 30, 2014. 
cess to public unemployment insurance benefits. As shown above, the average disposable income of unemployed retail workers only amounted to one half of their previous income, and many of them faced serious consequences in their financial situation.

The survey respondents reported the extensive use of informal solutions in order to cope with income loss when they were unemployed. 50.3\% of the respondents received financial help from family members, and 33.3\% borrowed money from family members or friends in order to pay for monthly expenses such as food, rent and other bills. Moreover, $24.1 \%$ of respondents took out temporary loans or credits while $34.8 \%$ had to sell personal belongings for the same reason. $68.1 \%$ of the respondents used their savings. The following additional comments give us an idea of how individuals turn to such informal sources of help.

I had no savings. So I received help from family and friends to buy food and took out loans in order to pay my bills on time. When I first became unemployed, I took out several loans thinking I would be able to pay them back once I get a new job. I also sold the stuff I could live without at jumble sales and in second-hand markets.

I am lucky since I have a partner and we pay a really low rent. I don't understand how others manage with those super-high rents in the city. The bank could also help us with a lower payment plan for our mortgage.

Informal welfare, including all sorts of help an individual can get from family members, extended families, neighbors, friends and other informal networks (Arksey/Glendinning 2007) has always played an important role. What the unemployed retail workers describe above is how informal welfare plays an indispensable role, not only during the time that they are waiting to receive unemployment benefits, but actually more or less constantly, even when benefits are being paid out. In a way, this is not surprising, as the average wage of a retail worker is rather low, and it is not particularly likely that they would have been able to create a large financial buffer to fall back on when facing unemployment.

\subsection{Illusory complementary pillar}

The establishment of complementary benefits for the unemployed has been extensive and the union for retail workers (Handels) also launched a complementary income insurance scheme for its members in 2007. This section sets out to explore the actual role of the complementary income insurance benefits for unemployed retail workers, given the inadequate income protection provided 
by the public pillar as described in the previous section. The individual data collected in the survey-based benefit recipiency study allow us to explore which unemployed retail workers actually received the complementary benefits and how this impacted them.

\subsubsection{Leaking bucket - from contractual right to actual benefit recipiency}

First of all, it is important to accurately map the survey respondents for which the complementary income insurance benefits might have been relevant, as these benefits are only accessible for those individuals who fulfill certain prerequisites in terms of previous income level and union membership. ${ }^{7}$ In an attempt to map which sub-groups among the survey respondents had access to complementary income insurance benefits, Figure 4 illustrates how they are divided into different categories in terms of the number of respondents.

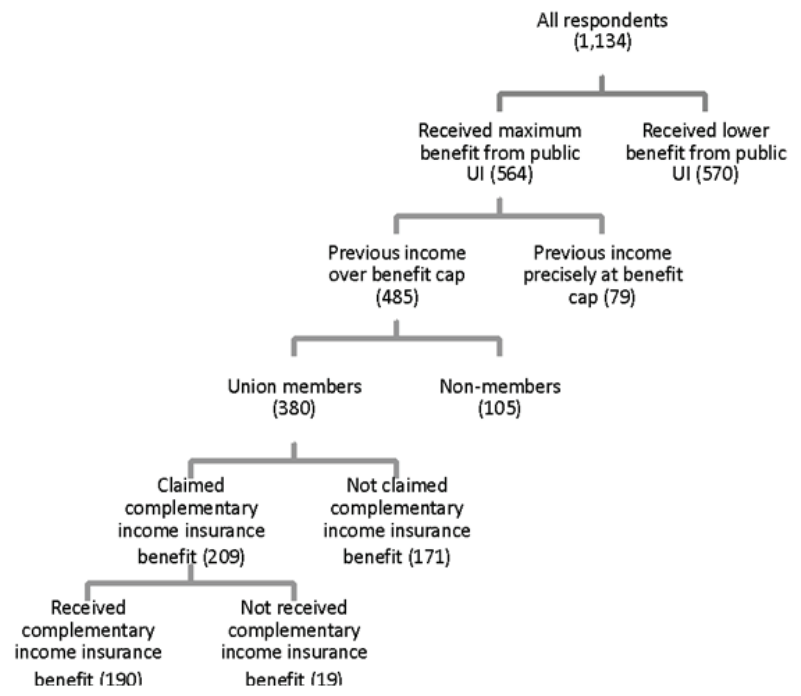

Figure 4: Recipients of complementary income insurance benefits

Source: Author's own calculation/data.

7 The basic eligibility requirements for receiving complementary income insurance benefits include being a member of the union for at least 12 months, that an individual's previous income is above the benefit ceiling in the public unemployment insurance program, and receiving earnings-related benefits. 
Out of 1,134 survey respondents, 564 individuals reported that they received SEK 680 as a daily benefit from the unemployment insurance fund, which is the maximum benefit amount. This corresponds to $49.7 \%$ of all respondents. Out of these, 485 individuals had a previous income above the benefit cap of SEK 18,700 (as of 2014), while the rest reported that their previous income corresponded exactly to the maximum amount of income compensated by the public unemployment insurance program (SEK 18,700). In total, 380 individuals (78.4\% of those receiving maximum benefits and with a previous income above the benefit cap) were members of the union Handels and would thus have been eligible to claim complementary income insurance benefits. Yet only 55\% (209 individuals) of them claimed these benefits and 190 individuals eventually received them. In other words, only around $17 \%$ of all respondents (190 individuals) received the complementary income insurance benefits. What can be noted here is a chain of different distributive logics at work that determine which of the unemployed retail workers actually have access to the complementary income insurance benefits. If access to the maximum public unemployment insurance benefits is determined by insurance fund membership as well as previous income level, for the complementary income insurance benefits, both union membership and the very act of claiming the benefits play a role. ${ }^{8}$

The result of several levels of selection leading to actual benefit recipiency, in what looks like a leaking bucket, is by no means arbitrary (Table 1). If we compare some of the demographic and labor market characteristics of the individuals receiving complementary income insurance benefits (right-hand column) with the group comprising those individuals who only receive the maximum benefits from the public unemployment insurance benefits (middle column), as well as with the entire population of survey respondents (left-hand column), we see that the average previous income of the recipients of complementary benefits is higher, and the proportion of temporary and part-time employment among them is lower, as compared to the two reference groups.

In other words, what we can see is that retail workers with a higher income and full-time and permanent employment are overrepresented among recipients of complementary income insurance benefits. While the average age and the proportion of Swedish-born among recipients of the complementary benefits is higher, the proportion of female individuals is lower compared to the two reference groups. Although the differences are not large, there is a clear hierarchical structure between the three groups being compared.

8 For an in-depth analysis of this non-take-up of the complementary income insurance benefit, see Lindellee (2018). 
Table 1: Characteristics of recipients of complementary income insurance benefits

\begin{tabular}{llll}
\hline & $\begin{array}{l}\text { All respondents } \\
(\mathbf{1 , 1 3 4 )}\end{array}$ & $\begin{array}{l}\text { Received maximum } \\
\text { benefits from public } \\
\text { Ul }(564 / 1,134)\end{array}$ & $\begin{array}{l}\text { Received public unem- } \\
\text { ployment benefit plus } \\
\text { complementary in- } \\
\text { come insurance bene- } \\
\text { fits (190/564) }\end{array}$ \\
\hline $\begin{array}{l}\text { Previous monthly in- } \\
\text { come (SEK) }\end{array}$ & 20,684 & 22,872 & 24,373 \\
$\begin{array}{l}\text { Share temporary em- } \\
\text { ployment (\%) }\end{array}$ & 30.5 & 25 & 13.8 \\
$\begin{array}{l}\text { Share part-time em- } \\
\text { ployment (\%) }\end{array}$ & 34.7 & 24.8 & 17.5 \\
$\begin{array}{l}\text { Average age } \\
\begin{array}{l}\text { Share female (\%) } \\
\text { Share Swedish-born (\%) }\end{array}\end{array}$ & 79.7 & 45 & 48 \\
\hline
\end{tabular}

Source: Author's own calculation/data.

In crude terms, older, Swedish-born male workers with labor market insider characteristics (higher income and more stable employment prior to unemployment) are more represented in unemployed retail sector workers receiving complementary income insurance benefits. As the complementary benefits require an individual to have been a member of the union for at least 12 months, the pattern of unionization is naturally reflected here; in other words, younger workers, non-Swedish workers and those facing unstable employment are underrepresented among union members (Kjellberg 2017a). Hence, the organizational patterns of the union members are directly reflected in the extent to which an unemployed person's income loss is compensated by this complementary pillar.

The establishment of the union-provided complementary income insurance schemes covering half the working population today surely represents an extensive institutionalization of the private pillar. However, this complementary pillar seems to be rather illusory for many unemployed retail workers, whose access to its benefits is limited due to the chains of multiple distributive logics that are at work. 


\subsubsection{Complementary income insurance benefit in action}

Understanding the role of complementary income insurance benefits demands a closer examination of the differences these additional benefits have made for the unemployed. Thus, the following analysis examines whether receiving complementary income insurance benefits had any impact on the financial situation of the unemployed retail workers. By comparing survey responses indicating both objective and subjective experiences of financial difficulties during unemployment, we can tease out the impact of complementary income insurance benefits for those individuals receiving the maximum daily benefit from the public unemployment insurance system. Thus, the following analysis only includes 564 individuals receiving the maximum daily benefit from the public unemployment insurance system, as this is a prerequisite for receiving complementary income insurance benefits.

To begin with, I compared the mean scores for disposable income during a period of unemployment between those individuals who only received the maximum benefits from the public unemployment insurance system and those individuals who also received complementary income insurance benefits. The mean difference in disposable income between the two groups is SEK 1,283 (average per month) and this difference is statistically significant. ${ }^{9}$ Next, I conducted the bivariate correlation analysis using cross-tabulation and a Chi-square test to examine whether receiving complementary income insurance benefits had any meaningful impact on an individual's financial situation, including variables measuring the degree of financial hardship, as well as the use of informal solutions during a period of unemployment.

As summarized in Table 2, the Pearson's Chi-square tests indicate that receiving complementary income insurance benefits in addition to public unemployment benefits has a significant correlation with whether an unemployed retail worker had a financial margin to meet unexpected expenses during a period of unemployment according to the definition of the EU-SILC survey. The results also indicate that receiving complementary benefits also meant that people did not have to ask family, relatives or friends for money. Also, those individuals receiving complementary benefits had to sell fewer belongings or

9 The group receiving complementary income insurance benefits ( $N=190, M=12447.89$, $\mathrm{SD}=4496.285$ ) had a higher average disposable income compared to the group only receiving public unemployment insurance benefits ( $\mathrm{N}=374, \mathrm{M}=11165.32, \mathrm{SD}=3672.614)$. The independent t-test was significant in the following conditions: $t(320,780)=3.396, p=.001$. 
were late with payments to a lesser extent, and these correlations are statistically significant.

Table 2: Impact of complementary income insurance benefits

\begin{tabular}{lll}
\hline & $\begin{array}{l}\text { Pearson Chi-square } \\
\text { value }\end{array}$ & P-value \\
\hline Financial margin for unexpected expenses & 4.690 & $.030^{\star}$ \\
Help from family and relatives & 13.132 & $.000^{\star \star}$ \\
Borrowing from friends & 10.549 & $.001^{\star \star}$ \\
Selling personal belongings & 5.400 & $.020^{\star}$ \\
Use of temporary loans and credits & .141 & .707 \\
Use of savings & .194 & .660 \\
Being late with payments & 8.849 & $.003^{\star \star}$ \\
Reducing necessary spending & .375 & .540 \\
Engaging in informal work & .478 & .489 \\
Partner's extra work & 1.355 & .244 \\
Difficulty in making ends meet & .062 & .804 \\
Long-term financial problems such as debt & 3.147 & .076 \\
\hline
\end{tabular}

Source: Author's own calculation/data

However, there were some other aspects in which the recipiency of complementary benefits did not result in any statistically significant differences. Receiving complementary benefits did not have any statistically significant correlations with aspects such as the use of temporary loans/credits and savings, having to reduce necessary spending, such as social activities, pension savings, etc., engaging in informal work or a partner's extra work. Nor did receiving complementary benefits have any statistically significant correlations concerning the extent to which the unemployed individual had difficulties in making ends meet or ended up with long-term financial problems, such as debt.

One possible way of interpreting this result is that the complementary benefits helped unemployed persons avoid having to turn to the most immediate and extreme way of solving the problem of financial liquidity. The most significant impact of the complementary benefits was found in terms of, for example, whether an individual had to ask for help from family and relatives or were late with payments. On the other hand, the complementary benefits did not seem to have led to any meaningful difference with regards to more long-term adjust- 
ments or strategies that unemployed persons had to adopt, such as having to reduce living expenses or a partner having to work extra, etc.

For the specific population of unemployed retail sector individuals who generally have a relatively low income, the role of complementary income insurance benefits seems to be meaningful in the sense that they make some difference. That includes in terms of the extent to which an unemployed person had to adopt extreme ways of solving the problem of financial liquidity, but were also limited in that the payment amount was rather small (on average SEK 2,200 per month). Whether this is to be considered a small amount is naturally a matter of interpretation. It is small in relation to what a group of highincome earners would have received from their complementary income insurance scheme. However, considering that the maximum amount that can be received from the public unemployment insurance program amounted to just above SEK 10,000 per month after taxation, a 20\% higher disposable income could have meant a lot for some individuals, depending on their life situation. Nonetheless, receiving these complementary income insurance benefits did not completely alleviate the financial vulnerabilities and difficulties with which they were faced. As the amount of complementary income insurance benefits for those individuals with a much higher income would also be higher, compared to the ceiling in the public unemployment insurance system, it is likely that the impact of receiving the complementary income insurance benefits for high-income earners would be more significant.

\section{Conclusion}

The changes in Swedish unemployment benefit provision in the last two decades arguably represent a case of shifting, blurring and mixing of responsibilities between different pillars, leading to a certain degree of risk privatization. In this study, the distributive outcomes of the multi-pillar system of unemployment benefit provision were analyzed by focusing on the benefit recipiency of unemployed retail sector workers. As for this particular labor market sector, the public pillar of the unemployment benefit provision system in Sweden is crumbling in two senses: for half of them, earnings-related benefits effectively became flat-rate benefits and do not guarantee full income compensation when they become unemployed. At the same time, eligibility rules and administrative procedures are increasingly regarded as counterproductive and burdensome for many unemployed retail workers who oscillate between precarious employment and the unemployment benefit system. As for complementary income insurance 
benefits, the overall pattern of benefit recipiency points to the reinforced outsiderness of the relatively weaker groups in the labor market, as the individuals with more labor market insider characteristics were overrepresented among those who had access to the benefits.

The current Swedish multi-pillarized unemployment benefit provision system guarantees full compensation for loss of income for some workers, with access to maximum benefits from the public pillar and complementary benefits from the occupational or private pillars. The story here, then, is that the retrenchment of the public pillar has been successfully compensated by the institutionalization of the complementary pillars. For those individuals at a very low risk of becoming unemployed, the system guarantees very generous protection, while those individuals facing a constant impending risk of unemployment and underemployment have difficulties in dealing with financial problems, even when they have access to both public unemployment and complementary income insurance benefits.

This discrepancy in the realities of labor market insiders and outsiders, on the one hand, and the increasingly more fragmented and stratified unemployment benefit provision system, on the other, ought to receive more attention in the public debate. After all, it is likely that the role of the complementary pillars and their interaction with the public pillar will continue to inform future development by affecting the willingness of politicians to reform, as well as the unions' vested interests in the governance of the different pillars of the unemployment benefit provision system.

Moreover, the subjective experiences of unemployed retail workers in their actual encounter with the benefit system are sources of important insights in rethinking an institution, such as the unemployment insurance program, with origins in obsolete assumptions from the industrial era. In order to engage in a serious discussion about how to recalibrate an unemployment benefit system that is capable of catering to the needs of the increasing number of labor market outsiders in the post-industrial economy, it is important to take into account the ways in which some retail workers move in and out of part-time unemployment, which is a great illustration of the blurred boundary between being unemployed and being in the world of precarious work. 


\section{Bibliography}

Arbetsförmedlingen (2016): Subventionerade anställningar. Kartläggning ur ett bransch och företagsperspektiv. Stockholm: Arbetsförmedlingen.

Arksey, Hilary; Glendinning, Caroline (2007): “Informal Welfare”, in: Martin Powel (ed.): Understanding the Mixed Economy of Welfare. Bristol: Policy Press, 107-128.

Berggren, Cecilia; Carlén, Stefan (2016): En dålig affär. En studie av otrygga anställningar i detaljhandeln. Handels utredningsgrupp. Stockholm: Handelsanställdas förbund.

Berglund, Tomas; Håkansson, Kristina; Isidorsson, Tommy; Alfonsson, Johan (2017): “Temporary Employment and the Future Labor Market Status", Nordic Journal of Working Life Studies 7(2): 27-48.

Boman, Josefine; Berge, Agneta (2013): Hit men inte längre? En rapport om deltider, välfärdspolitik och målet om en jämlik arbetsmarknad. Handels utredningsgrupp. Stockholm: Handelsanställdas förbund.

Boman, Josefine; Strömbäck, Anton (2014): Otrygghet och flexibilitet. Om anställningsvillkor och konsekvenser av arbetsgivares bemanningspolitik i handel. Handels utredningsgrupp. Stockholm: Handelsanställdas förbund.

Carlén, Stefan; Berg, Elina (2015): I arbete eller åtgärd? En studie av arbetsplatsförlagda insatser i handeln. Handels utredningsgrupp. Stockholm: Handelsanställdas förbund.

Carlén, Stefan; Boman, Josefine (2013): Har sänkta arbetsgivaravgifter hjälpt unga att få jobb i handeln? Handels utredningsgrupp. Stockholm: Handelsanställdas förbund.

Coulter, Kendra (2014): Revolutionizing Retail: Workers, Political Action, and Social Change. New York: Palgrave Macmillan.

Davidsson, Johan Bo; Emmenegger, Patrick (2013): “Defending the organisation, not the members: Unions and the reform of job security legislation in Western Europe", European Journal of Political Research 52(3): 339-363.

Davidsson, Johan; Naczyk, Marek (2009): The Ins and Outs of Dualisation: A Literature Review. Working Papers on the Reconciliation of Work and Welfare in Europe, REC-WP Nr.2. Edinburgh: Publication, Dissemination and Dialogue Centre (PUDIAC) of RECWOWE.

Ebbinghaus, Bernhard (2011): The Varieties of Pension Governance: Pension Privatization in Europe. Oxford: Oxford University Press.

Egebark, Johan; Kaunitz, Niklas (2013): Sänkta arbetsgivaravgifter för unga. Rapport 2013:26. Uppsala: Institutet för arbetsmarknads- och utbildningspolitisk utvärdering (IFAU).

Ferragina, Emanuele; Seeleib-Kaiser, Martin (2011): “Thematic Review: Welfare regime debate: past, present, futures?”, Policy \& Politics 39(4): 583-611.

Gordon, Joshua C. (2019): “The Perils of Vanguardism: Explaining Radical Cuts to Unemployment Insurance in Sweden”, Socio-Economic Review 17(4): 947-968.

Hacker, Jacob S. (2004): "Privatizing risk without privatizing the welfare state: The hidden politics of social policy retrenchment in the United States", American Political Science Review 98(2): 243-260.

Häusermann, Silja; Schwander, Hanna (2012): “Varieties of dualization? Labor market segmentation and insider-outsider divides across regimes”, in: Patrick Emmenegger; Silja Häusermann; Bruno Palier; Martin Seeleib-Kaiser (eds.): The Age of Dualization: The Changing Face of Inequality in Deindustrializing Societies. Oxford: Oxford University Press, 27-51. 
Hernanz, Virginia; Malherbet, Franck; Pellizzari, Michele (2004): Take-Up of Welfare Benefits in OECD Countries: A Review of the Evidence. OECD Social, Employment and Migration Working Papers 17.

Kjellberg, Anders (2017a): “Fack, arbetsgivare och industrial relations”, in: Mattias Bengtsson; Tomas Berglund (eds.): Arbetslivet. Lund: Studentlitteratur, 229-268.

Kjellberg, Anders (2017b): Kollektivavtalens täckningsgrad samt organisationsgraden hos arbetsgivarförbund och fackförbund. (1 red.). Studies in Social Policy, Industrial Relations, Working Life and Mobility. Research Reports; Vol. 2017, Nr. 1. Lund: Department of Sociology, Lund University.

Korpi, Walter; Palme, Joakim (1998): “The Paradox of Redistribution and Strategies of Equality: Welfare State Institutions, Inequality, and Poverty in the Western Countries”, American Sociological Review 63(5): 661-687.

Kvist, Jon; Greve, Bent (2011): “Has the Nordic Welfare Model Been Transformed?", Social Policy \& Administration 45(2): 146-160.

Larsson, Mats (2015): Arbetstider år 2015. Heltids- och deltidsarbete, vanligen arbetad tid samt arbetstidens förläggning efter klass och kön år 1990-2015. Stockholm: Landsorganisationen i Sverige.

Lindellee, Jayeon (2018): Beyond Retrenchment: Multi-Pillarization of Unemployment Benefit Provision in Sweden. Lund Dissertations in Social Work. Lund: Lund University.

Lindquist, Gabriella Sjögren; Wadensjö, Eskil (2007): Ett svårlagt pussel - kompletterande ersättningar vid inkomstbortfall. Rapport till Expertgruppen för Studier i Samhällsekonomi 2007:1. Stockholm: Finansdepartementet, Regeringskansliet.

Lindquist, Gabriella Sjögren; Wadensjö, Eskil (2011): Avtalsbestämda ersättningar, andra kompletterande ersättningar och arbetsutbudet. Rapport till Expertgruppen för studier $\mathrm{i}$ offentlig ekonomi 2011:4. Stockholm: Finansdepartementet, Regeringskansliet.

Meyer, Traute; Bridgen, Paul; Riedmüller, Barbara (2007): Private Pensions versus Social Inclusion? Non-State Provision for Citizens at Risk in Europe. Cheltenham: Edward Elgar.

Palier, Bruno; Thelen, Kathleen (2010): “Institutionalizing Dualism: Complementarities and change in France and Germany”, Politics \& Society 38(1): 119-148.

Palme, Joakim; Bergmark, Åke; Bäckman, Olof; Estrada, Felipe; Fritzell; Lundberg, Olle; Sjöberg, Ola; Szebehely, Marta (2002): "Welfare trends in Sweden: balancing the books for the 1990s", Journal of European Social Policy 12(4): 329-346.

Rasmussen, Peter (2014): Privatizing unemployment protection - The rise of private unemployment insurance in Denmark and Sweden. CCWS Working paper no. 2014-83. Centre for Comparative Welfare Studies (CCWS), Department of Political Science, Aalborg University.

Rönnmar, Mia; Numhauser-Henning, Ann (2012): "Swedish Employment Protection in Times of Flexicurity Policies and Economic Crisis”, International Journal of Comparative Labour Law and Industrial Relations 28(4): 443-467.

SCB (2014): Fyra av tio i EU saknar marginal för oförutsedda utgifter. 2014-11-25. Undersökningarna av levnadsförhållanden (ULF/SILC). Statistiska centralbyrån.

SCB (2016): Sysselsatta efter näringsgren 2006-2015. Employed persons by branch of activity during the years 2006-2015. Sveriges Officiella Statistik. Statistiska Meddelanden AM 110 SM 1604. Statistiska centralbyrån.

SCB (2017): Lönespridning efter sektor och kön 2017. Lönestrukturstatistik. Statistiska centralbyrån. 
Sebardt, Gabriella (2005): Redundancy and the Swedish Model: Swedish Collective Agreements on Employment Security in a National and International Context. PhD dissertation. Uppsala: lustus förlag.

Seeleib-Kaiser, Martin; Saunders, Adam M.; Naczyk, Marek (2011): “Social Protection Dualism, De-Industrialization and Cost Containment”, in: David Brady (ed.): Social Protection Dualism, De-Industrialization and Cost Containment. Research in the Sociology of Work. Volume 22. Emerald, 83-118.

SSR (2014): Försörjningsstödstagare Riket 2013. Stockholm: Akademikerförbundet SSR.

Standing, Guy (2014): The Precariat. The New Dangerous Class. London et al.: Bloomsbury. van Oorschot, Wim (2013): “Comparative Welfare State Analysis with Survey-Based Benefit Recipiency Data: The Dependent Variable Problem Revisited”, European Journal of Social Security 15(3): 224-248.

Vedin, Ulrika (2016): Sveriges jämställhetsbarometer 2016. Tid, makt och pengar. Tema: Lön. Enheten för ekonomisk politik och arbetsmarknad. Stockholm: Landsorganisationen i Sverige.

Wiß, Tobias (2015): “From welfare states to welfare sectors: Explaining sectoral differences in occupational pensions with economic and political power of employees", Journal of European Social Policy 25(5): 489-504.

\section{Short Biography}

Jayeon Lindellee is a postdoctoral researcher at the School of Social Work at Lund university. In her PhD dissertation she studied the role of labor unions in shaping the historical and ongoing development of the Swedish unemployment insurance system. As a postdoctoral researcher she has two lines of ongoing research, one focusing on sociological inquiries into the leadership strata of major civil society organizations in several European countries and the other focusing on deliberative processes involving citizens to integrate the perspective of ecological sustainability in social policy development in Sweden. 